\title{
THE VOICE OF THE CHURCH IN MODERN PROBLEMS
}

THE business of the Church in the world is twofold : to teach and to aid. She has to set out the divine truths, issue moral warnings, rebuke and exhort in season and out of season; further, she has the custody of those sacred signs which carry with them the grace of God, and through the communication of which the souls receiving them are enabled to carry out these divine precepts and exhortations. She teaches to the world about her the ideals of Christ, and she gives to the world the power of Christ whereby these ideals can be realised. In short, to use words which have become familiar to this generation, we can say that the Church has to perform the functions both of a priest and a prophet.

Now, if in view of these two functions we were to try to judge the Church of our own time in as detached a fashion as we could, we should probably agree that the priestly side of the Church's office is being performed with a zeal and a response such as no other age of her history can have surpassed. To dogmatise on historical parallels between one age and another would be foolish, because impossible of verification or proof : yet the closest student of history would, I believe, be hard put to discover a period of Christian development when the sacramental system was so much frequented as it is to-day. Merely to consult any of the popular spiritual manuals of the last four centuries and to contrast them with those of to-day is to make one realise the enormous increase of sacramental devotion that has been made in these last years. Naturally during the period covered by

${ }^{2}$ An address delivered at C.T.S. Meeting, Manchester. 


\section{The Voice of the Church in Modern Problems}

this long stretch of time we find local evidences of much priestly development through the ministration of individual saints like St. Paul of the Cross or St. Alphonsus Liguori, or again, through the work of the religious communities they founded; but it is difficult to prove that these were anything more than merely local till one gets back into the heart of the CounterReformation, which centres round the figures of St. Ignatius, St. Teresa, St. Philip Neri and St. Charles.

Precisely, however, what is now most noticeable is that this frequent attendance of the Sacraments is not merely local, but is widespread everywhere throughout all Christendom. Places here and there may be exceptional foci of devotion; but even apart from these, the common level of devotion is higher, or, to alter the metaphor, the heat of its flame is greater, than for many generations. Shall we name Pope Pius $\mathrm{X}$, with his short reign and yet vibrant faith, as the great apostle of this sudden outburst? Yet even so, the beginnings go back further, to the aftermath of the French Revolution. That first broke up the soil that had before been caked and hardened. The new birth of bewildering numbers of religious congregations of women dates from then; there is hardly one of them that does not go back for its beginnings to France and the Revolution. Next after it came Rosmini, as a rallying centre to the new devotion, and an inspiration, half-way betwixt the Revolution and Pius X.

The result is plain for all to see. Ask at the convents, where altar breads are made, whether the number of communicants has not steadily increased, and the answer will only confirm what I have said, and indeed, what everyone would state as irrefutable.

But the prophetical office of the Church? Should we be quite so convinced that this also is as well carried out as the other? What precisely do we mean by the prophetical office? It means, shall we say, a con- 


\section{Blackfriars}

tinuation of that moral exhortation which the prophets of the Old Dispensation so flamingly began. The burden of their prophecy was not foretelling so much as forthtelling the things of God. We do indeed hear much of predictions, of visions, of dumb shows, which foretold events, as when Elizeus bade Joas strike the ground with his arrows and prophecied afterwards that as many times as he had smitten the earth, should he smite Syria (IV Kings, 13). But far more important were the denunciations of evil and the pointing of the way to good, with which all the prophets of the Old Testament were so inflamed. ${ }^{2}$

The prophetic office, then, of the Church includes all this. She has to forthtell to the people the things of God, and she has to do this in virtue of her continuance of the work of her Master; for the office of Prophet did not cease with the closing of the Old Testament. St. John the Baptist was not the least of the prophets, though in the mere sense of Messianic forthtelling he may well have been the last. He did more than merely point out our Lord to his disciples. as the Lamb of God Who came to take away the sins of the world, or send these disciples to Him to enquire whether He were the Messias, for it was the work of the Baptist no less to take up that other burden of his predecessors : 'Do penance, for the Knigdom of God is at hand.' 'Do penance,' that is the forthtelling of his official position.

2 Compare the following from the English translation of the Summa Theologica: "It is requisite to prophecy that the intention of the mind be raised to the perception of Divine things : wherefore it is written (Ezechiel II, 1): Son of man stand upon thy feet and $I$ will speak to thee. This raising of the intention is brought about by the motion of the Holy Ghost, wherefore the text goes on to say: And the Spirit entered into me and $\mathrm{He}$ set me upon my feet. After the mind's intention has been raised to heavenly things, it perceives the things of God; hence the text continues: And I heard Him speaking to me.' (Second Part of Second Part, Quest. 171, 1, ad $4 \mathrm{~m}$, p. 4). 


\section{The Voice of the Church in Modern Problems}

When our Lord came, $\mathrm{He}$ also had His message; $\mathrm{He}$ foretold the future, but $\mathrm{He}$ preached the Kingdom. He looked out into the ages and revealed the things that were to be hereafter; far more did He devote Himself to setting out before His hearers and those who were to follow in every succeeding generation, the spirit in which life was to be met, the security born of the sense of God's protecting fatherhood. He not only preached this, but lived it. To repeat our phrase, He foretold and forthtold.

Now, what He did, the Church was to do after Him. She was to continue His work, to repeat His predictions and His message. But we have suggested, and indeed, we want to urge, that while the priestly office of the Church is being abundantly and faithfully carried out, it does not seem that her prophetical office is receiving equal attention and development. Perhaps you may think that in saying this I am ignoring the great part taken by the Church in warning her people and the world against the evils of. our time. You recall the masterly encyclicals of Leo XIII, of Pius X, of Benedict XV; you would point out, perhaps, how, one by one, political lawlessness, social injustice, false nationalism, the moral crimes of divorce and artificial birth-control, have been denounced by the Pontiffs, and you may think that I must be forgetting these if I presume to lecture the Church on her failure to live up to her prophetical office. Far from it. I remember all these great acts well. For the moment, however, I am referring neither to the Popes nor to their warnings. In fact, I am not referring to warnings at all. Firstly, I am putting aside altogether the business, so to call it, of scolding; and secondly, I am considering not the prelates but ordinary folk, for the Church does not consist of Pontiffs and prelates only; she includes you and me, and we are here not to discuss the proper duties of the papacy, but the deficiencies of ourselves. 


\section{Blackfriars}

Now, I would like to suggest that where we fail, or if you prefer it, where we do not wholly succeed, is in this : that while we frequent the Sacraments dutifully and regularly, we do not attend with equal dutifulness and regularity to another work no less really demanded of us-not the work of scolding, but of setting before the world the ideals of Catholic life. Thus, let me formulate what I want to say in three sentences:

(a) The world needs ideals.

(b) The Catholic Church needs ideals.

(c) These Catholic ideals are not sufficiently brought forward by us.

No one will quarrel with the assertion of the first couple of propositions. Will anyone deny that the last is not of equal importance with the first two?

Take, for example, the world of politics. There are many Catholics in politics, fortunately in every part and in every group. What have these Catholic politicians done in public to rebuke the lack of idealism in their own party? No doubt they are as ready to criticise the moral failure of their opponents as anyone else: but do they as vigorously criticise the moral failures of their own side. Now, please do not answer that we can take it for granted that this has been done in private, for it is precisely on this point that, it seems to me, that the matter turns. It is not private protestations that we need, but public protestations by Catholics against the evil actions, policies, or subterfuges of their own party.

Perhaps one could state this particular evil very briefly by merely saying that we Catholics are too much like everybody else. We do not seem to show (and I would insist on the word 'seem' as the very reason for this paper) to any marked advantage in the world of political life. 


\section{The Voice of the Church in Modern Problems}

Catholics in journalism, again, seems no less uncharitable, their statements as unprovable, their criticism as ill-natured as that of anyone else. I am not specifically referring to the Catholic religious press, which does not actually pretend to treat of party matters, though, of course, none of our papers can wholly keep clear of party distinctions, for their readers do buy the Catholic Times or Universe or Tablet or Catholic Herald to suit their politics. This political instrusion into our religious press cannot be helped, and, indeed, is probably much to be desired. But what I am rather thinking of is the Catholic journalist who writes for the great neutral press, and who is in a position, by his ideas and ideals, to uphold principles superior to the prejudices of his own party's passions. It is here that the Catholic journalist can do a very much needed work; not that he should be always expressing or expounding the Catholic faith. Obviously that is quite outside his direct duty; but he would admit that he could devote himself more than he does to the propagating of those common ideals. that all men and parties do in their hearts acclaim.

May I be frank and take for a moment the question of the late war? The Catholic Church will not let us say that war cannot be justifiable. She teaches that defensive war can be good, that swords can be blest, that a crusade may be a holy thing. We do not therefore hold war to be wrong in itself. Further, there is no need to argue over again whether the late war was justified or not. What is more to our point is that it is within the memory of all of us that Pope Benedict XV made various efforts towards peace. He wrote and spoke on several occasions, urging that something should be done to end the strife. Yet no one paid any attention to his words. Largely because he was a Pope, he was judged before he had spoken. That one could have expected from the non-Catholic press. But 


\section{Blackfriars}

why were there so few Catholic journalists to defend him? Oh, I grant that even the clergy left him as severely alone as did the press. Yet somehow it happened that when President Wilson proclaimed his fourteen points, everyone praised him to the skies. The Morning Post, I believe, which had denounced the Pope, accepted the President, implying that not the proposals, but their source, had been the reason for their non-acceptance. Here, surely, the Catholic journalists could have done good work. They were numerous. They were powerful. They could have argued in favour, not of the Pope as Pope, but of his proposals, or, at least, have set high the ideals at which he aimed. Yet we Catholics were all as blood-thirsty as the rest of the civil population, and made the killing of the Germans the prime object of our inspiring addresses.

Or take again the Catholic men of business or of trade. We are for ever telling the world that we have the real principles through which alone its salvation is to come. We speak of the encyclicals of Leo XIII, and the position of the working man, which those encyclicals determine. We say-and no doubt rightly -that the Catholic Church has the social remedies within the store-cupboard of her moral teaching. But at the moment of a strike or lock-out, where do Catholics appear? I mean not the prelates but the laity, who sit among employers and employed, on Boards of Guardians, on Town and City Councils. Do they behave any differently from their fellows? The answer may be given that a Catholic's views on disputes in trade are his own, and do not come under the judgment of the Church. Then what is the use of our talking about the Catholic Church as containing in her teaching the cure of the world's ills if in the moment of need individual Catholics do nothing to enlighten. modify, or inspire the schemes of their 502 


\section{The Voice of the Church in Modern Problems}

group or party? Either we have principles that are unique or not. If we have, then our lives and policies should be unique; if we have not, then what is the use or where is the honesty of all our talk?

Nor is it wise to wait for other people to move, or to wait for England to become Catholic before attempting to set society upon its true basis; if our faith be divine, our teachings real and true, we must be the first ourselves to begin and now at once to make all our policies conform to the Gospel teaching. The employer must consider his duty to his men : he cannot wait for his fellow-employers to act, he must do what he thinks best.

The same is true of the Catholic landlord; of Catholic labour. Each of us in our professional position must try in grave matters to stand outside our party claims; in the world, though not of it. We must judge, act, rebuke more fearlessly than others, because we ought to see more clearly where our moral duty points the way. Nor are such acts disloyal to our party or our side; on the contrary they are-if our faith be divine-the truest and noblest loyalty.

Have we not all of us, priest or layman, to confess that we have far too of ten allowed prejudice to blind us? that we have followed our party and not the teaching of Christ? followed and not led? To act otherwise would mean that we should perhaps have to suffer from unpopularity, but we should at least have done something to save the people.

If instead of devoting our time and attention to the wearisome task of controversy, we endeavoured to make plain the ideals of the faith by speech and action, we should, perhaps, succeed the more quickly in our work of converting the country and of holding our own body to the Church.

On several occasions I have been privileged by the C.E.G. to speak at their meetings in Hyde Park and 503 


\section{Blackfriars}

elsewhere, and the effect of these meetings on me has been to make me believe that the C.E.G. does as fine a work as that done by any of our societies to-day. None the less, I believe that work to be only one-half -and that the easier half-of the business of Catholics in England. On the very last occasion but one on which I spoke in Hyde Park, as I came down from the platform I passed a group of working men, who had put questions to me, and who were eagerly talking among themselves as I passed them by; so eagerly, indeed, that, though I wore my habit, they did not notice that I was at their side. None of them were Catholics; they were working men, they were all opposed to me; but their questions as regards the teaching of the Church I had been able to answer without much difficulty. But as I passed, I overheard the most eager of the group say to the others : "Their theories are all right, but it is only a theory. For the rest they are no different from any of us.'

I confess that this saying touched me to the quick, and made me ashamed, not of others, but of myself. What use is it for the forward movement of the C.T.S., or for the C.E.G. to proceed with their zealous and edifying work all over the countryside, preaching and explaining and setting high the ideals of the faith, unless we ourselves live up individually to those ideals? What good can talking do, so long as we journalists or politicians, employers or employed, priests or parents, simply copy the prejudices or follow the passions, of the class or group to which we belong, or, at least, are too timid to oppose them?

The Englishman has a profound reverence for facts. To our people it is facts that will tell, and not platforms, in the bringing of them to the faith.

Now, the office of the Church is prophetic as well as priestly; she has to preach the faith as well as establish the sacraments, and of that Church the laity 504 


\section{The Voice of the Church in Modern Problems}

are as much members as are the clergy. The Church, whether in its priests or in its people, has admirably responded to the priestly obligations of the altar. The frequenting of confession and communion, the admirable Guilds of the Blessed Sacrament, the welcome sight of the badges of the knights and handmaids of the Blessed Sacrament are without parallel, perhaps, in the whole history of the Church in this country. But what, we repeat, of the prophetic office? the teaching and its practice of the faith?

What shall we say of these to-day? We have an animated forward movement of C.T.S. We have the massed efforts of the C.E.G. and of the Ransom Guild. But we want something more. We want, all of us, lives lived in the high altitudes of the Spirit, above prejudice and partisanship, yet applied to the realms of national development and international justice. We need to have above the quibbles of casuistry as to murder and freedom, above denunciations that are merely uncharitable and unfair, a detachment of spirit that shall be free, austere, idealistic, and Catholic.

That is the voice of the Church in the modern social problems which has, it seems to me, most need to be heard, the unstudied eloquence of Catholic example with its nobler spirit and surer means. Nor will anyone, I think, question the statement that such intrepid Catholic lives would find a ready recognition and response amongst the dwellers in these islands, who are looking everywhere for leading as well as. light, and are turning to us as their last hope, as one of them has said, 'the last Church of the West to retain the affections of the poor.'

The world awaits us; shall it be said of us hereafter that it was we who failed?

Bede Jarrett, O.P. 